University of Nebraska - Lincoln

DigitalCommons@University of Nebraska - Lincoln

Faculty Publications from the Harold W. Manter Laboratory of Parasitology

$2-1-2000$

\title{
Arthropod and Helminth Parasites from the Plains Pocket Gopher, Geomys bursarius bursarius from the Hosts' Northern Boundary Range in Minnesota
}

\author{
Monroe H. Bartel \\ Moorehead State University \\ Scott Lyell Gardner \\ University of Nebraska - Lincoln, slg@unl.edu
}

Follow this and additional works at: https://digitalcommons.unl.edu/parasitologyfacpubs

Part of the Parasitology Commons

Bartel, Monroe H. and Gardner, Scott Lyell, "Arthropod and Helminth Parasites from the Plains Pocket Gopher, Geomys bursarius bursarius from the Hosts' Northern Boundary Range in Minnesota" (2000). Faculty Publications from the Harold W. Manter Laboratory of Parasitology. 28.

https://digitalcommons.unl.edu/parasitologyfacpubs/28

This Article is brought to you for free and open access by the Parasitology, Harold W. Manter Laboratory of at DigitalCommons@University of Nebraska - Lincoln. It has been accepted for inclusion in Faculty Publications from the Harold W. Manter Laboratory of Parasitology by an authorized administrator of DigitalCommons@University of Nebraska - Lincoln. 
J. Parasitol., 86(1), 2000 p. 153-156

(C) American Society of Parasitologists 2000

\section{Arthropod and Helminth Parasites from the Plains Pocket Gopher, Geomys bursarius bursarius from the Hosts' Northern Boundary Range in Minnesota}

Monroe H. Bartel and Scott L. Gardner*, Department of Biology, Moorhead State University, Moorhead, Minnesota 56563; and *Harold W Manter Laboratory of Parasitology, University of Nebraska-Lincoln, Lincoln, Nebraska 68588-0514

ABSTRACT: As part of a continuing and more general study of the diversity of parasites from subterranean mammals in central North America, individuals of the Plains Pocket Gopher, Geomys bursarius bursarius, were collected from 7 localities in northwestern Minnesota from September 1991 through October 1996. Arthropods collected included the fleas, Opisocrostis bruneri ( 4 of 124, 3.2\%), Foxella ignota ignota ( 85 of 124, 68.5\%); the chewing louse, Geomydoecus geomydis geomydis from 98 of 124 (79\%), and larvae of the tick, Dermacentor variabilis (1 of 124, 0.8\%). Nematodes found included Physaloptera limbata ( 2 of 118 gophers, 1.7\%), Capillaria americana (4 of 118, 3.4\%), and Ransomus rodentorum ( 31 of $118,26.3 \%$ ). Cestodes recovered included Anoplocephaloides infrequens (12 of 136 gophers, 8.8\%), Anoplocephaloides variabilis (19 of 136, 14\%), Andrya macrocephala (20 of 136, 14.7\%), and Hymenolepis weldensis from 12 of 136, 8.8\%. The acanthocephalan, Moniliformis clarki was found in 1 of 118 gophers $(0.8 \%)$. No parasites were found in the cheek pouches, thoracic, or peritoneal cavities.

Pocket gophers (Geomyidae), primarily southern Nearctic and extreme northern Neotropical in distribution, are subterranean mammals that only infrequently leave their burrows (Hall, 1981). The Plains Pocket Gopher, Geomys bursarius (Shaw) complex, which consists of about 21 subspecies, occurs in the midwestern and southern United States from Texas to southern Manitoba (Canada), and from Illinois to Wyoming and New Mexico (Hall, 1981).

Few data exist concerning the parasites of the subspecies, Geomys bursarius bursarius, which occupies Minnesota near the northern limit of its range (records also being from southern Manitoba), but searching in marginal localities for this species by R. L. Rausch (pers. comm. to S.L.G.) revealed possible local extirpation of this species. From collections made in Minnesota, Douthitt (1915) described the cestodes, Andrya macrocephala, Anoplocephaloides infrequens, and Anoplocephaloides variabilis, and Timm and Price (1980) collected Geomydoecus geomydis.

Studies of the arthropods and helminths of other subspecies of $G$. bursarius report cestodes and nematodes from Oklahoma (Burnham, 1953); Hymenolepis from the midwestern states (Douthitt, 1915); Hymenolepis spp. from Colorado (Gardner and Schmidt, 1988); Foxella from North Dakota (Larson, 1997); Geomydoecus, Foxella, and Acari from Colorado (Miller and Ward, 1960); Geomydoecus and Foxella from South Dakota (Rissky, 1962); Geomydoecus and Acari from Illinois and Missouri (Spicka, 1981); Geomydoecus from throughout the host's range (Timm and Price, 1980); Geomydoecus, Foxella, and Acari from Indiana (Tuszynski and Whitaker, 1971); and Andrya, Anoplocephaloides, and Nemata from Kansas (Ubelaker and Downhower, 1965).

We examined 144 individuals of $G$. $b$. bursarius for the presence of both endo- and ectometazoan parasites collected from 7 localities in Minnesota. We found 2 species of fleas, 1 species of lice, 1 species of tick, 3 species of nematodes, 4 species of cestodes, and 1 species of Acanthocephala. Seven new host and 6 new locality records are reported (Table I).

Gophers were trapped using Victor Macabee gopher traps, placed in plastic bags, cooled on ice, and taken to the laboratory. Traps were checked every few minutes and gophers removed as soon as they were captured. Ectoparasites were brushed from the fur with a fine brass brush into an enamelcoated tray and preserved in $70 \%$ ethanol. Cheek pouches and cavities of the thorax and abdomen were examined for parasites. The contents of the stomachs, small intestines, large intestines, and cecae were separately washed over a 100-mesh screen, the screenings of which were examined for helminths in a petri dish using a dissecting microscope.

Cestodes found were relaxed in ice water and, after death, were immediately fixed in hot buffered formalin. Other helminths were fixed directly in buffered formalin. Standard techniques of dehydrating, clearing, staining, and mounting of parasites were used (Dailey, 1996). Voucher specimens have been 
TABLE I. Prevalence (\%) and mean intensity (range) of parasites found in the plains pocket gopher from 7 localities in Minnesota.

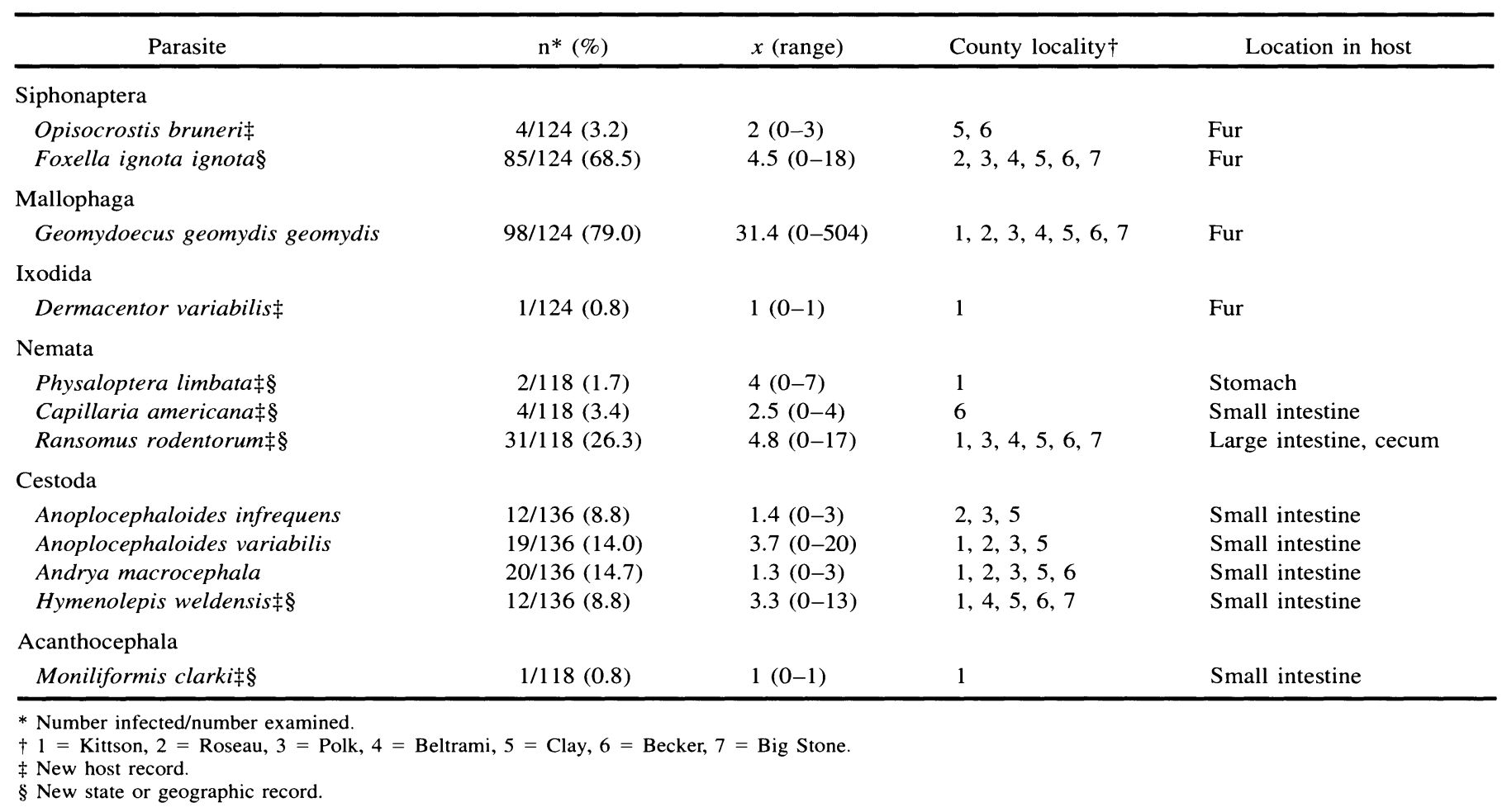

deposited in the Harold W. Manter Laboratory of Parasitology (HWML), University of Nebraska-Lincoln: Opisocrostis bruneri (HWML14802-14803), Foxella ignota ignota (HWML14804-14812), Geomydoecus geomydis geomydis (HWML14813-14824), Physaloptera limbata (HWML14931), Capillaria americana (HWML14930), Ransomus rodentorum (HWML14922-14929), Anoplocephaloides infrequens (HWML14789-14792), A. variabilis (HWML14787-14788), Andrya macrocephala (HWML14798-14801), Hymenolepis weldensis (HWML14793-14795), and Moniliformis clarki (HWML14948). Specimens of Dermacentor variabilis (26.1X.1966) have been deposited with the Institute of Arthropodology and Parasitology, Statesboro, Georgia.

Siphonaptera (fleas) were represented by the genera Opisocrostis and Foxella. Species of Opisocrostis (syn. Oropsylla) are common on ground squirrels (Spermophilus spp.) and prairie dogs (Cynomys spp.) (Hubbard, 1968). The species Oropsylla bruneri, occurring from Michigan and Indiana westward into eastern Montana, is found on species of Spermophilus and its ecological associates and inquilines including the Northern Pocket Gopher, Thomomys talpoides (Larson, 1997). This is the first record of $O$. bruneri from gophers, with this species infesting $4(3.2 \%)$ of the gophers examined (Table I).

The Pocket Gopher Flea, $F$. ignota, currently with 11 subspecies, is widespread in northern North America, where it occurs on various rodents (Hubbard, 1968; Larson, 1997). Foxella i. ignota has been reported to occur on $G$. b. bursarius from the Rocky Mountains east to the Mississippi River. This flea has also been reported from $T$. talpoides in eastern North Dakota (Larson, 1997). Rissky (1962) recovered it from 50 (26\%) of $G$. bursarius examined in in South Dakota. Foxella i. ignota occurred on $85(68.5 \%)$ of the gophers we collected and represents a new state record.

Timm and Price (1980), in their extensive study of chewing lice of the order Mallophaga from the 23 described subspecies of $G$. bursarius, list 15 species and subspecies of Geomydoecus exclusively from this host. Geomydoecus g. geomydis is the only subspecies of chewing louse occurring on $G$. b. bursarius from Kansas northward (Price and Emerson, 1971). Ninetyeight $(79 \%)$ of the gophers examined were infested with this louse (Table I), representing a new host record.

The tick, $D$. variabilis is abundant in eastern North America, westward to the Mississippi basin, with several disjunct populations occurring in southern Canada and the midwestern and western United States including limited records from the western and eastern borders of Minnesota (Sonenshine, 1979). Larva feed predominantly on Peromyscus, Clethrionomys, and $\mathrm{Mi}$ crotus (Atwood and Sonenshine, 1967; Burachynsky and Galloway, 1985). Miller and Ward (1960) reported 1 larva from Thomomys bottae (Southern Pocket Gopher) in Colorado. In our study, 1 larva was collected from 1 gopher $(0.8 \%)$ (Table I). These low levels of infestation suggest that larval $D$. variabilis are rare ecological associates of gophers.

Nematodes of the genera Physaloptera, Capillaria, and Ransomus were found in this study (Table I). Physaloptera limbata occurred in $2(1.7 \%)$ of the gophers collected, a new host and state record. This nematode was reported by Leidy (1856) from the stomach of Scalops canadensis (syn. Scalopus aquaticus) in Pennsylvania; from S. aquaticus in Wisconsin, Missouri, Indiana, Ohio, Kansas, and Iowa; from Parascalops breweri in Maryland, Vermont, and New Hampshire; and from Blarina brevicauda in Illinois and Wisconsin (Morgan, 1946). 
Capillaria americana was reported from the intestine of Glaucomys volans (type host), Sciurus carolinensis, Peromyscus maniculatus, and Peromyscus leucopus from Illinois (type locality), Ohio, and Wisconsin; from 5 (22\%) of Dipodomys ordii in Utah (Frandsen and Grundman, 1961); and from Tamiasciuris hudsonicus, Neotoma magister, P. leucopus, and Clethrionomys gapperi in Maryland (Lichtenfels and Haley, 1968). Four (3.4\%) of the gophers examined were infected (Table I), representing new host and locality records.

The rodent hookworm, Ransomus rodentorum was found in the cecae and large intestines of $31(26.3 \%)$ of the gophers examined (Table I), representing a new host and distribution record. This gopher-specific nematode was reported by Hall (1916) from $T$. talpoides (type host) in Colorado; Frandsen and Grundman (1961) from both T. talpoides (46\%) and Thomomys umbrinus (0.04\%) in Utah; Todd et al. (1971) from $78 \%$ of $T$. talpoides examined in Wyoming; Jasmer (1980) from T. bottae in northern California; and by Gardner (1985) from Thomomys bulbivorus $(11 \%)$ in the Willamette Valley of Oregon (Gardner, 1985).

Four species of cestodes representing the genera Anoplocephaloides, Andrya, and Hymenolepis occurred in the intestines of $63(46.3 \%)$ of the gophers. Anoplocephaloides infrequens Douthitt, 1915 was recovered from the intestine of $12(8.8 \%)$ of the animals examined (Table I). This cestode was reported by Douthitt (1915) from G. b. bursarius (type host) in Minnesota and Manitoba, Canada; Rausch (1976) from G. b. bursarius in Minnesota; Ubelaker and Downhower (1965) from 6 $(50 \%)$ of $G$. b. bursarius in Kansas; Todd et al. (1971) from 7 (15\%) of $T$. talpoides in Wyoming; Frandsen and Grundmann (1961) from T. talpoides in Wyoming; and Hansen (1950) from $9(17 \%)$ of Microtus ochrogaster in Nebraska. Nineteen (14\%) of the gophers examined harbored $A$. variabilis (Table I). This cestode was reported by Douthitt (1915) from the intestine of G. b. bursarius (type host) from Minnesota, North Dakota, Manitoba, and Illinois; Rausch (1976) from 5 (31\%) of T. talpoides in Saskatchewan and $1(17 \%)$ in Manitoba; Frandsen and Grundmann (1961) from T. talpoides in Utah; Todd et al. (1971) from $18(38 \%)$ in T. talpoides from Wyoming; and Lubinsky (1957) from T. talpoides from Alberta. Andrya macrocephala Douthitt, 1915 was found in 20 (14.7\%) of the gophers examined (Table I). Douthitt (1915) reported this cestode from G. b. bursarius (type host) from Minnesota; Rausch and Schiller (1949) from Thomomys talpoides tenellus in Wyoming, from Sigmodon hispidus in North Carolina, from Microtus sp. from Ohio, Michigan, Wisconsin, Manitoba, Wyoming, Illinois, Nebraska, Washington, and in Ondatra from Ohio; Hansen (1950) from $5(100 \%)$ of $G$. bursarius from Nebraska; and Lubinsky (1957) in Microtus, Pedomys, and Clethrionomys from Alberta. The cestode, $H$. weldensis Gardner and Schmidt, 1988 was recovered from $12(8.8 \%)$ of the gophers examined (Table I), a new host subspecies and state geographic record. This cestode was reported by Gardner and Schmidt (1988) from 3\% of Geomys bursarius lutescens (type host) from Colorado.

Moniliformis clarki (phylum Acanthocephala) was recovered from the small intestine of $1(0.8 \%)$ of the animals examined (Table I). This species was first described by Ward (1917) from squirrels. Van Cleave (1953) lists records of various mammalian host species including Geomys bursarius illionensis from Illinois; Erickson (1938) recovered Moniliformis sp. (consid- ered Moniliformis clarki by VanCleave, 1953) from P. maniculatus in Minnesota; Rausch and Tiner (1948) (M. clarki?) from Eutamias in Minnesota; McLeod (1933) from Citellus in Manitoba; Fish (1972) from Microtus (19\%) in Indiana; Chandler (1947) from Sciurus and Glaucomys in Florida; Pfaffenberger et al. (1985) from Onychomys in New Mexico; and Frandsen and Grundmann (1961) from $1(0.03 \%)$ of Thomomys umbrinus stansburyi and $4(0.01 \%)$ of Peromyscus in Utah.

No parasites were noted or recovered from the cheek pouches, thoracic, pleural, or abdominal cavities of the gophers that were examined.

We gratefully acknowledge Moorhead State University Alumni Association for a research grant; Omar Larson, University of North Dakota (retired) for identification of the fleas; Roger Price, University of Minnesota (retired) for identification of the lice; and James Keirans, Institute of Arthropodology and Parasitology, Georgia Southern University, Statesboro for identification of the larval tick.

\section{LITERATURE CITED}

Atwood, E. L., AND D. E. Sonenshine. 1967. Activity of the American dog tick, Dermacentor variabilis (Acarina: Ixodidae), in relation to solar energy changes. Annals of the Entomological Society of America 60: 354-362.

BURACHYNSKY, V. I., AND T. D. GALlOWAY. 1985. Seasonal dynamics and distribution of American dog tick, Dermacentor variabilis (Say), larvae and nymphs at Birds Hill Park, Manitoba. Canadian Journal of Zoology 63: 2748-2755.

Burnham, G. L. 1953. A study of the helminth parasites of the pocket gophers of Woods, Alfalfa, Grant, and Marshall Counties, Oklahoma. Proceedings of the Oklahoma Academy of Science 34: 59-61.

Chandler, A. C. 1947. Notes on Moniliformis clarki in North American squirrels. Journal of Parasitology 33: 278-281.

DaILy, M. D. 1996. Meyer, Olsen, and Schmidt's essentials of parasitology, 6th ed. W. C. Brown, Dubuque, Iowa, 287 p.

DouthitT, H. 1915. Studies on the cestode family Anoplocephalidae. Illinois Biological Bulletin 1: 355-446.

ERICKSON, A. B. 1938. Parasites of some Minnesota Cricetidae and Zapodidae, and a host catalogue of helminth parasites of native American mice. American Midland Naturalist 20: 575-589.

FISH, P. G. 1972. Notes on Moniliformis clarki (Ward) (Acanthocephala: Moniliformidae) in west central Indiana. Journal of Parasitology 58: 147.

Frandsen, J. C., AND A. W. Grundman. 1961. Endoparasitism in isolated populations of rodents of the Lake Bonneville Basin, Utah. Journal of Parasitology 47: 391-396.

GARDNER, S. L., AND G. D. SChMidT. 1988. Cestodes of the genus $H y$ menolepis Weinland, 1858 sensu stricto from pocket gophers Geomys and Thomomys spp. (Rodentia: Geomyidae) in Colorado and Oregon, with a discriminant analysis of four species of Hymenolepis. Canadian Journal of Zoology 66: 896-903.

Hall, M. C. 1916. Nematode parasites of mammals of the orders Rodentia, Lagomorpha, and Hyracoidea. Proceedings of the U.S. National Museum 50: 1-258.

Hall, E. R. 1981. The mammals of North America. John Wiley and Son, New York, New York, ca. 1,200 p.

Hansen, M. F. 1950. A new dilepidid tapeworm and notes on other tapeworms of rodents. American Midland Naturalist 43: 471-479.

Hubbard, C. A. 1968. Fleas of western North America, their relation to the public health. Hafner Publishing Co., New York, New York, $533 \mathrm{p}$.

JASMER, D. P. 1980. The parasites of the Botta pocket gopher, Thomomys bottae and the taxonomy and the biology of Ransomus rodentorum. M.S. Thesis. Humbolt State University, Arcata, California, 37 p.

LARSON, O. R. 1997. North Dakota fleas. X. An atlas of the state's Siphonaptera. Research Report No. 47, Institute for Ecological Studies, University of North Dakota, Grand Forks, 77 p. 
LEIDY, J. 1856. A synopsis of entozoa and some of their ecto-congeners observed by the author. Proceedings of the Academy of Natural Sciences, Philadelphia 8: 42-58.

Lichtenfels, J. R., AND A. J. HALEY. 1968. New host records of intestinal nematodes of Maryland rodents and suppression of Capillaria bonnevillei Grundman and Frandsen, 1960 as a synonym of $C$. americana Read, 1949. Proceedings of the Helminthological Society of Washington 35: 206-211.

LUBINSKY, G. 1957. List of helminths from Alberta rodents. Canadian Journal of Zoology 35: 623-627.

MCLEOD, J. A. 1933. A parasitological survey of the genus Citellus in Manitoba. Canadian Journal of Research 9: 108-126.

MilleR, R. S., AND R. A. WARD. 1960. Ectoparasites of pocket gophers from Colorado. The American Midland Naturalist 64: 382-391.

Morgan, B. B. 1946. A redescription of Physaloptera limbata Leidy, 1856 (Nematoda: Physalopterinae). Journal of Parasitology 32: 6971.

Pfaffenberger, G. S., K. Kemether, and D. DeBruin. 1985. Helminths of sympatric populations of kangaroo rats (Dipodomys ordii) and grasshopper mice (Onychomys leucogaster) from the high plains of eastern New Mexico. Journal of Parasitology 71: 592-595.

Price, R. D., AND K. C. Emerson. 1971. A revision of the genus Geomydoecus (Mallophaga: Trichodectidae) of the new world pocket gophers (Rodentia: Geomyidae). Journal of Medical Entomology 8: $228-257$.

RausCH, R. L. 1976. The genera Paranoplocephala Lühe, 1910 and Anoplocephaloides Baer, 1923 (Cestoda: Anoplocephalidae), with particular reference to species in rodents. Annals de Parasitologie (Paris) 51: 513-561.

-, AND E. L. SChILler. 1949. A critical study of North American cestodes of the genus Andrya with special reference to A. macro- cephala Douthitt, 1915. (Cestoda: Anoplocephalidae). Journal of Parasitology 35: 306-314.

, AND J. D. TINER. 1948. Studies on the parasitic helminths of the North Central States. I. Helminths of Sciuridae. American Midland Naturalist 39: 728-747.

Rissky, R. W. 1962. Parasites of the plains pocket gopher, Geomys bursarius (Shaw) in Clay County, South Dakota. Proceedings of the South Dakota Academy of Science 41: 83-90.

SONENSHINE, D. E. 1979. Zoogeography of the American dog tick, Dermacentor variabilis. In Recent advances in acarology, Vol. 2, J. R. Rodriguez (ed.). Academic Press, New York, New York, p. 123-134.

SPICKA, E. J. 1981. Ectoparasites and other arthropod associates on two subspecies of plains pocket gophers: Geomys bursarius illinoensis and Geomys bursarius missouriensis. Canadian Journal of Zoology 59: $1903-1908$.

Timm, R. M., AND R. D. PRICE. 1980. The taxonomy of Geomydoecus (Mallophaga: Trichodectidae) from the Geomys bursarius complex (Rodentia: Geomyidae). Journal of Medical Entomology 17: 126-145.

TODD, K. S., D. L. LEPP, AND C. A. TRYON. 1971. Endoparasites of the northern pocket gopher from Wyoming. Journal of Wildlife Diseases 7: 100-104.

TUSZYNSKI, R. C., AND J. O. WhITAKER, JR. 1971. External parasites of pocket gophers, Geomys bursarius, from Indiana. American Midland Naturalist 87: 545-548.

UbelakeR, J. E., AND J. F. Downhower. 1965. Parasites recovered from Geomys bursarius in Douglas county, Kansas. Transactions of the Kansas Academy of Science 68: 206-208.

VAN ClEAVE, H. J. 1953. Acanthocephala of North American mammals. Illinois Biological Monographs, Nos. 1-2, University of IllinoisUrbana, Illinois 23: 1-179.

WARD, H. B. 1917. "Echinorhynchus moniliformis" in North America. Journal of Parasitology 3: 141 . 